\title{
Geophysical investigation of seamounts near the Ogasawara Fracture Zone, western Pacific
}

\author{
Tae-Gook Lee ${ }^{1}$, Kiehwa Lee ${ }^{2}$, James R. Hein ${ }^{3}$, and Jai-Woon Moon ${ }^{4}$ \\ ${ }^{1}$ Development Operations Team, Korea National Oil Corporation, 1588-14, Anyang 431-711, Korea \\ ${ }^{2}$ School of Earth and Environmental Sciences, Seoul National University, Seoul 151-747, Korea \\ ${ }^{3}$ U.S. Geological Survey, 345 Middlefield Rd., MS 999, Menlo Park, CA, 94025-3591, USA \\ ${ }^{4}$ Marine Resources Research Department, Korea Ocean Research and Development Institute, \\ Ansan P.O. Box 29 425-600, Korea
}

(Received October 13, 2004; Revised October 9, 2008; Accepted October 21, 2008; Online published March 3, 2009)

\begin{abstract}
This paper provides an analysis of multi-channel seismic data obtained during 2000-2001 on seamounts near the Ogasawara Fracture Zone (OFZ) northwest of the Marshall Islands in the western Pacific. The OFZ is unique in that it is a wide rift zone that includes many seamounts. Seven units are delineated on the basis of acoustic characteristics and depth: three units (I, II, and III) on the summit of seamounts and four units (IV, V, VI, and VII) in basins. Acoustic characteristics of layers on the summit of guyots and dredged samples indicate that the seamounts had been built above sea level by volcanism. This was followed by reef growth along the summit margin, which enabled deposition of shallow-water carbonates on the summit, and finally by subsidence of the edifices. The subsidence depth of the seamounts, estimated from the lower boundary of unit II, ranges between 1,550 and $2,040 \mathrm{~m}$. The thick unit I of the southern seamounts is correlated with proximity to the equatorial high productivity zone, whereas local currents may have strongly affected the distribution of unit I on northern seamounts. A seismic profile in the basin around the Ita Mai Tai and OSM4 seamounts shows an unconformity between units IV and V, which is widespread from the East Mariana Basin to the Pigafetta Basin.
\end{abstract}

Key words: Ogasawara Fracture Zone, acoustic characteristics, subsidence depth, unconformity.

\section{Introduction}

The western Pacific is characterized by its abundant seamounts and fracture zones with variable orientations. Wessel and Kroenke (1997) suggested that more than 8,800 seamounts exist in the Pacific, most of them in the western Pacific. Most of the seamounts in the western Pacific originated from intraplate volcanisms (Sager, 1992). Using data obtained on drill cores and some of the seamounts of the Marshall Islands, several researchers have investigated the complex interactions among Pacific intraplate volcanism, seafloor uplift and subsidence, reef-building, and sealevel change (e.g., Schlanger et al., 1981, 1987; Lincoln et al., 1993). Studies of seamounts are important because seamounts contains a record of the tectonic history of the plate. Most of the seamounts in the western Pacific have been studied using dredged rock samples, shallow sediment cores, and geophysical data, and for only a very few have deep drill cores been taken for direct study. In addition, of the latter, many were focused on a search for mineral resources, such as ferromanganese crusts, and the data are proprietary.

Originally proposed as extensions of transform faults on spreading ridges, it has been suggested more recently that fracture zones record the spreading direction of the plate.

Copyright (c) The Society of Geomagnetism and Earth, Planetary and Space Sciences (SGEPSS); The Seismological Society of Japan; The Volcanological Society of Japan; The Geodetic Society of Japan; The Japanese Society for Planetary Sciences; TERRAPUB.
Fracture zones can be detected by differences in seafloor depth, discontinuity of magnetic anomaly lineations, and disruption of the acoustic layers in seismic profiles. Most of the fracture zones in the western Pacific have been clearly identified from an analysis of magnetic anomaly lineations (Nakanishi et al., 1989, 1992)_particularly in cases where it has been difficult to identify seafloor depth differences due to the widespread layer of thick sediment disguising the depth difference. Fracture zones may control the variable thickness of the sediment layer owing to different basement depths.

Geophysical data were obtained over seven seamounts northwest of the Marshall Islands in 2000 and 2001 during reconnaissance surveys of seamounts for ferromanganese crusts carried out by the Korea Ocean Research and Development Institute (KORDI) using the R/V Onnuri. The Ogasawara Fracture Zone (OFZ) crossing the study area separates the East Mariana Basin (EMB) and Pigafetta Basin (PB), which are parts of the oldest Pacific plate (Fig. 1). Among the fracture zones of the western Pacific, the OFZ is somewhat unique in that it is a wide rift zone that includes many submarine volcanoes (e.g., Magellan Seamounts and submarine volcanoes on the Dutton Ridge). We have investigated the acoustic characteristics of these seamounts on seismic profiles of the $\mathrm{PB}, \mathrm{EMB}$, and OFZ, even though the seismic lines were too short to completely cover the basins. We also investigated the characteristics of acoustic layers on the summit of seamounts to clarify their sedimentary history. The DSDP and ODP sites in the EMB, PB, and OFZ 


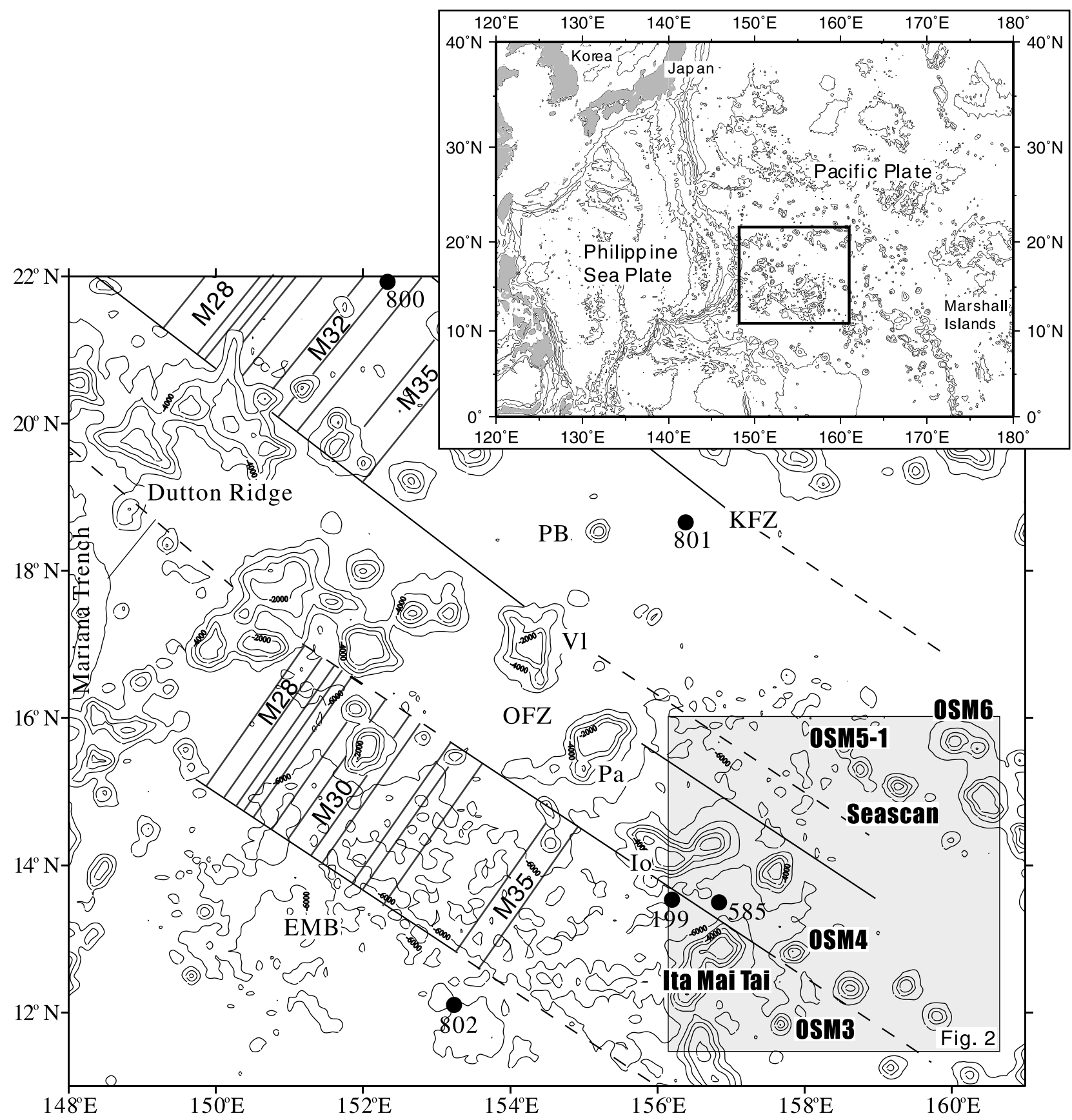

Fig. 1. Location map of the study area delineated by the box in the main panel. The magnetic anomaly lineations are based on Jurassic geomagnetic reversals for oceanic basement (M28 = 158-159 Ma; M32 = 161-162 Ma; M35 = $164 \mathrm{Ma})$. The Ogasawara fracture zone (OFZ) crosses the study area (after Nakanishi et al., 1989, 1992; Koppers et al., 1998). In the Magellan seamount trail, Vlinder (95.1 Ma) is abbreviated as VI, Pako (91.3 Ma) as Pa, and Ioah (87.1 Ma) as Io (Koppers et al., 1998). KFZ denotes Kashima Fracture Zone. ODP Sites 800 and 801 are located in the Pigafetta Basin (PB) and ODP Site 802 in the East Mariana Basin (EMB). DSDP Sites 199 and 585 are close, but located in different subbasins of the PB and OFZ, respectively.

near the study area were used as tie points.

\section{Geological Settings}

The study area lies on the Jurassic ocean crust, which is the oldest part of the Pacific plate, and is crossed by the OFZ (Fig. 1). The OFZ impinges on the Izu-Ogasawara Trench to the northwest, and its southeastern boundary is ambiguous because of insufficient data. Multi-channel seismic profiles (Abrams et al., 1992) have revealed that the OFZ is a $150-\mathrm{km}$-wide rift zone with sharp bounding walls that are perpendicular to the surrounding magnetic lineations. Based on the magnetic anomaly lineation M35 between the $\mathrm{PB}$ and $\mathrm{EMB}$, it has been estimated that there has been about a $600-\mathrm{km}$ movement between these two points (Fig. 1) (Nakanishi et al., 1989). The drill core of Ocean Drilling Program (ODP) sites 800 and 802 in the PB and EMB did not reach the oceanic crust, while the drill cores of ODP site 801 in PB indicates that the crust is as old as $167 \mathrm{Ma}$ (Pringle, 1992). The drill cores at DSDP site 585 in the OFZ also failed to reach basement, even though it penetrated to $893 \mathrm{~m}$ below the sea floor (mbsf) (Moberly et al., 1986). Based on a study of the cores and seismic pro- 


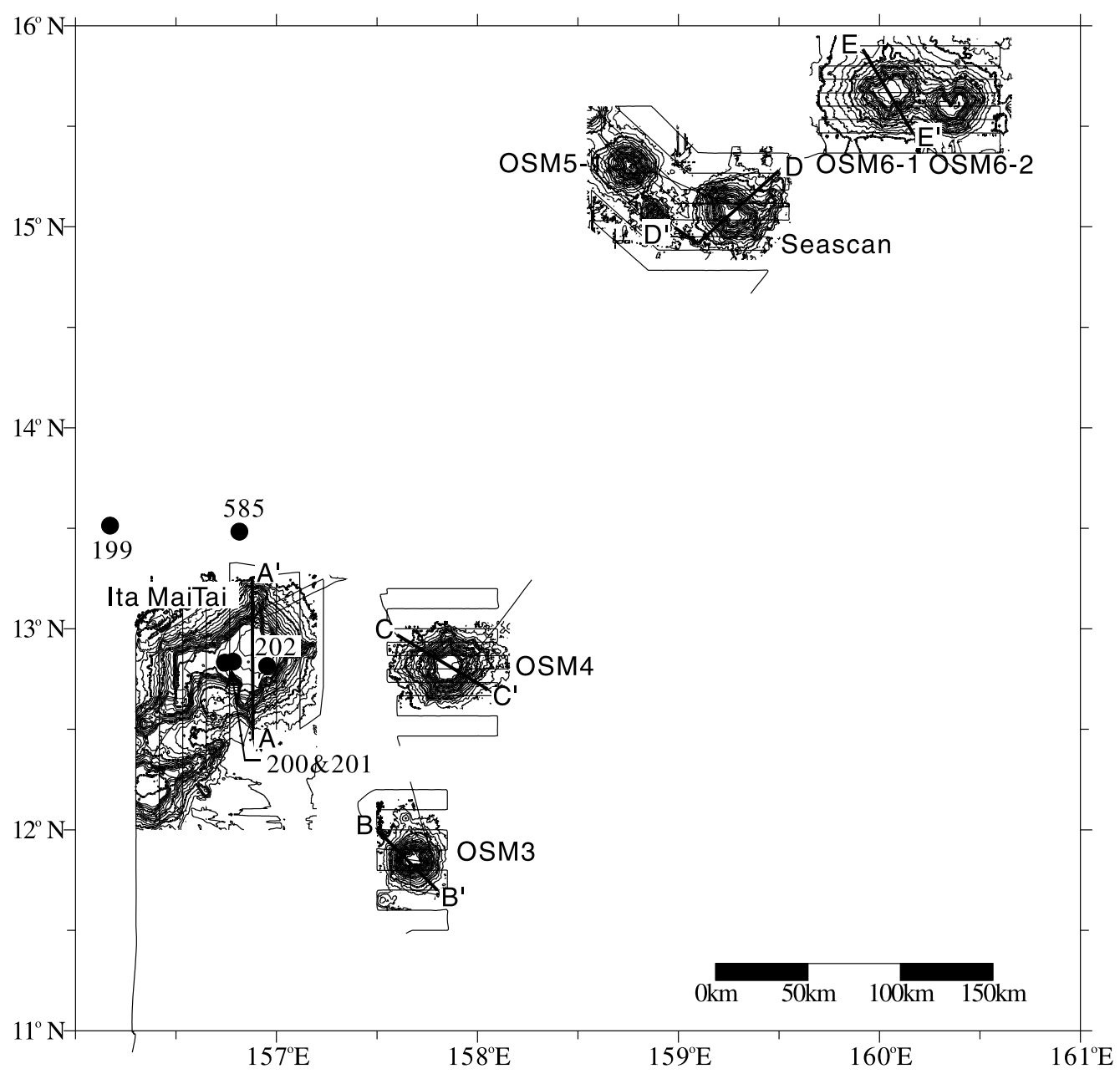

Fig. 2. Bathymetric map of the seamounts in the box of Fig. 1. Contour interval is $200 \mathrm{~m}$. Thin solid lines indicate ship tracks and thick solid lines $\left(\mathrm{AA}^{\prime}-\mathrm{EE}^{\prime}\right)$ seismic survey lines (see Figs. 3 and 4). Numbers are DSDP Sites.

files across the OFZ, Abrams et al. (1992) concluded that the thickness of sediment over the basement in the OFZ is greater than that in the EMB.

Most of the seamounts that we investigated in the study reported here have been mapped recently using modern multi-beam echosounder and denoted sequentially by KORDI. These seamounts are named OSM1, OSM3, OSM4, OSM5-1, OSM5-2, and OSM6, with OSM6 denoted as having subclusters OSM6-1 and OSM6-2 (Fig. 2). OSM1 and OSM5-2 were previously named Ita Mai Tai and Seascan, and those original names are also used here. Most volcanism in the study area is associated with seamountisland (hot-spot) chains, such as the Magellan/MarcusWake Seamounts of Early Aptian age (Lancelot et al., 1990; Winterer et al., 1993) and the Marshall/Gilbert seamounts of Albian and Paleocene age (Lincoln et al., 1993). The seamounts of the study area are divided into three sectors based on location: seamounts in the EMB (Ita Mai Tai and OSM3) linked to the Magellan Seamounts, the one in the OFZ trough (OSM4), and those linked to the Marshall Islands (OSM5-1, Seascan, and OSM6).

Ita Mai Tai has been drilled, age-dated, and surveyed using gravity, seismic, subbottom, and magnetic methods (Heezen et al., 1973b, c; Sager, 1983; Koppers et al., 1998; Lee et al., 2003, 2005). Its summit consists of a pelagic cap, oolitic limestone, and lagoonal mud based on Deep Sea Drilling Project (DSDP) sites 200-202. Extrapolation of the Neogene sedimentation rates of the drill cores suggests that there is either a sedimentation hiatus between the Early Eocene and Early Miocene or a marked reduction in sedimentation rate, resulting in a condensed sequence (Heezen et al., 1973b, c). Koppers et al. (1998) estimated the age of Ita Mai Tai to be 118 Ma based on radiometric age dating of dredged rock samples. Sager (1983) and Lee et al. (2003) investigated the paleomagnetism of seamounts in the study area and proposed that the poles of most seamounts cluster along the 129-72 Ma paleopole path.

All seamounts we examined are guyots with a flat summit, except for OSM5-1 (Fig. 2). In plan view, Ita Mai Tai is "L"-shaped, whereas the others are nearly circular. Ita Mai Tai has well-defined flank rift zones, which are steep and have bladelike sheets (dikes and sills) that parallel and bisect the rift zone. In our study area, depths to the base of slope range from 5,300 to $6,000 \mathrm{~m}$ (Table 1 ). The water depth to the summits ranges from 1,085 to $1,350 \mathrm{~m}$. Flat-summit margin depths lie between 1,300 and 1,650 m. The southern seamounts are higher than the northern ones. The maximum diameter at the base of Ita Mai Tai is about $100 \mathrm{~km}$. The surface areas of the flat summit are as large as $650 \mathrm{~km}^{2}$, while the rest of the seamounts have a maximum 
Table 1. Summary of seamount morphology in the study area.

\begin{tabular}{|c|c|c|c|c|c|c|c|c|c|c|c|}
\hline & \multicolumn{2}{|c|}{ Location } & \multicolumn{3}{|c|}{ Depth } & \multirow[b]{2}{*}{$\begin{array}{l}\text { Height } \\
\text { (m) }\end{array}$} & \multirow{2}{*}{$\begin{array}{c}\text { Flat surface } \\
\text { summit } \\
\text { area }\left(\mathrm{km}^{2}\right)\end{array}$} & \multicolumn{2}{|c|}{ Diameter of base } & \multirow{2}{*}{$\begin{array}{c}\text { Average } \\
\text { slope } \\
\text { gradient }\left(^{\circ}\right) \\
\end{array}$} & \multirow{2}{*}{\begin{tabular}{|l|} 
Maximum \\
thickness of \\
unit $\mathrm{I}^{* *}(\mathrm{~m})$ \\
\end{tabular}} \\
\hline & $\begin{array}{c}\text { Longitude } \\
\text { (E) }\end{array}$ & $\begin{array}{l}\text { Latitude } \\
(\mathrm{N})\end{array}$ & $\begin{array}{l}\text { Summit } \\
\left(\mathrm{mbsl}^{*}\right)\end{array}$ & $\begin{array}{r}\text { Base } \\
(\mathrm{mbsl})\end{array}$ & $\begin{array}{c}\text { Flat summit margin } \\
\text { depth (mbsl) }\end{array}$ & & & $\begin{array}{c}\text { Major } \\
\text { axis }(\mathrm{km})\end{array}$ & $\begin{array}{c}\text { Minor } \\
\text { axis }(\mathrm{km})\end{array}$ & & \\
\hline Ita Mai Tai & $156^{\circ} 50^{\prime}$ & $12^{\circ} 50^{\prime}$ & 1,350 & 5,900 & 1,650 & 4,550 & 650 & 100 & 90 & 11.2 & 150 \\
\hline OSM3 & $157^{\circ} 40^{\prime}$ & $11^{\circ} 50^{\prime}$ & 1,260 & 5,900 & 1,550 & 4,640 & 70 & 40 & 35 & 13.7 & 45 \\
\hline OSM4 & $157^{\circ} 50^{\prime}$ & $12^{\circ} 50^{\prime}$ & 1,270 & 6,000 & 1,500 & 4,730 & 140 & 55 & 45 & 10.7 & 70 \\
\hline OSM5-1 & $158^{\circ} 45^{\prime}$ & $15^{\circ} 20^{\prime}$ & 1,205 & 5,500 & - & 4,295 & - & 40 & 35 & 11.5 & - \\
\hline Seascan & $159^{\circ} 15^{\prime}$ & $15^{\circ} 05^{\prime}$ & 1,150 & 5,500 & 1,300 & 4,350 & 80 & 55 & 45 & 12.7 & $<15$ \\
\hline OSM6-1 & $160^{\circ} 05^{\prime}$ & $15^{\circ} 40^{\prime}$ & 1,085 & 5,300 & 1,400 & 4,215 & 155 & 55 & 45 & 7.7 & $<15$ \\
\hline OSM6-2 & $160^{\circ} 20^{\prime}$ & $15^{\circ} 35^{\prime}$ & 1,225 & 5,300 & 1,400 & 4,075 & 70 & 45 & 40 & 9.2 & $<15$ \\
\hline
\end{tabular}

$*$ mbsl $=$ meters below sea level.

**Maximum thickness of unit I is identified from chirp data.

diameter of less than $55 \mathrm{~km}$ and a flat-summit surface area of less than $155 \mathrm{~km}^{2}$. The average gradient of the seamounts varies from $7.7^{\circ}$ to $13.7^{\circ}$ (Table 1 ). OSM6 generally has a gentle slope gradient, with the exception of a steep upper slope. Ita Mai Tai has a gentler upper slope than the others.

\section{Data Acquisition}

We obtained detailed bathymetric, multi-channel seismic, chirp (3-7 kHz) subbottom, and magnetic data along $5,120 \mathrm{~km}$ of geophysical survey lines (Fig. 2). Navigation was logged by a differential Global Positioning System (GPS). Multi-beam bathymetry was acquired by the SeaBeam 2000 and SeaLogger system. The bathymetric survey was conducted mainly in the N-S and E-W directions with approximately 7-km spacing, based on the seafloor coverage of SeaBeam 2000. Seismic data were obtained along one line per seamount, except for OSM6-2, for a total seismic line length of about $395 \mathrm{~km}$ (Fig. 2). The seismic data obtained on OSM5-1 were excluded from analysis in this study because distinctive acoustic layers did not exist on the peaked summit. Although seismic data obtained from each seamount are insufficient for a detailed analysis, the shallow acoustic structures are interpreted by subsidiary data and chirp subbottom profiles, which are extensive over all the seamounts. The total volume of the airgun and shot interval are $2.5^{*} 2 l$ and $12 \mathrm{~s}$, respectively during the 2000 cruise and $2.5 l$ and $15 \mathrm{~s}$, respectively, during the 2001 cruise. Data were acquired using a 12-channel streamer with a total active length of $75 \mathrm{~m}$. The sampling rate was $4 \mathrm{~ms}$ for the 2000 survey and $2 \mathrm{~ms}$ for the 2001 survey. The seismic data processing steps included gathering, constant velocity stacking, predictive deconvolution, amplitude recovery, and bandpass filtering.

\section{Characteristics and Interpretation of Acoustic Units}

In this study, the delineation of acoustic units on the flat summits was determined by comparing our data with those on drill cores and previously obtained seismic data on seamounts of the western Pacific. The interpretation of acoustic units from seismic sections taken from the basins is also based on seismic sections from drill core sites and the cores. Three acoustic units are identified on summits of the seamount: unit I, with either no internal reflectors or only weak ones; continuous and parallel internal reflectors; unit II characterized by either chaotic, incoherent, discontinuous, and hyperbolic internal reflectors, or by a transparent layer; unit III, which is characterized by semicontinuous and parallel strong internal reflectors (Fig. 3). Four units are identified beneath the deep-ocean basins around the seamounts: unit IV, with a transparent layer with weak and parallel internal reflectors overlapping the base of the seamounts; unit V, which is characterized by continuous high-amplitude internal reflectors; unit VI, which is characterized by intermittently discontinuous and irregular low-amplitude internal reflectors; a lower well-layered and thin high-amplitude unit (unit VII) (Fig. 4).

\subsection{Seismic stratigraphy of seamounts summit}

Unit I is lenticular- or dome-shaped and as thick as $0.15 \mathrm{~s}$ in two-way travel time (twtt) at the center of the summit of Ita Mai Tai (Fig. 3). Unit I has been interpreted as a pelagic cap by comparison with drill cores from DSDP sites 200-202 on Ita Mai Tai (Heezen et al., 1973b, c) and its maximum age estimated to be Middle Eocene based on the drill cores (Heezen et al., 1973b, c). Unit II has developed along the margin of the summit and has highamplitude reflectors that are distinct, although the lower boundary is indistinct (Fig. 3). Based on studies of western Pacific seamounts, unit II is interpreted to be a reef complex (Lincoln et al., 1993). Unit III, which is overlain by unit I, is widely distributed on the summit and is surrounded by unit II (Fig. 3). Based on drill cores of DSDP site 202 and the cores drilled from seamounts in the western Pacific, unit III is interpreted to be a shallow-water lagoonal deposit that is mainly composed of mud and fragments of reefal rock (Heezen et al., 1973c; Winterer et al., 1993). The reef complex had been deposited near the sea surface. The maximum thickness of units II and III on Ita Mai Tai is over 0.3 s twtt.

Seamounts with a flat summit in the study area have similar units to those of Ita Mai Tai, whether they are located in the PB or elsewhere, but unit I is much thinner than it is on Ita Mai Tai (Fig. 3). Based on chirp subbottom profiles (Lee et al., 2005), there is a distinct difference in the thickness of unit $\mathrm{I}$ between the northern and southern seamounts. The maximum thickness of unit I on Ita Mai Tai is about $150 \mathrm{~m}$, while the maximum thicknesses of OSM3 and OSM4 are 45 and $70 \mathrm{~m}$, respectively, while those of OSM5-2, OSM6- 

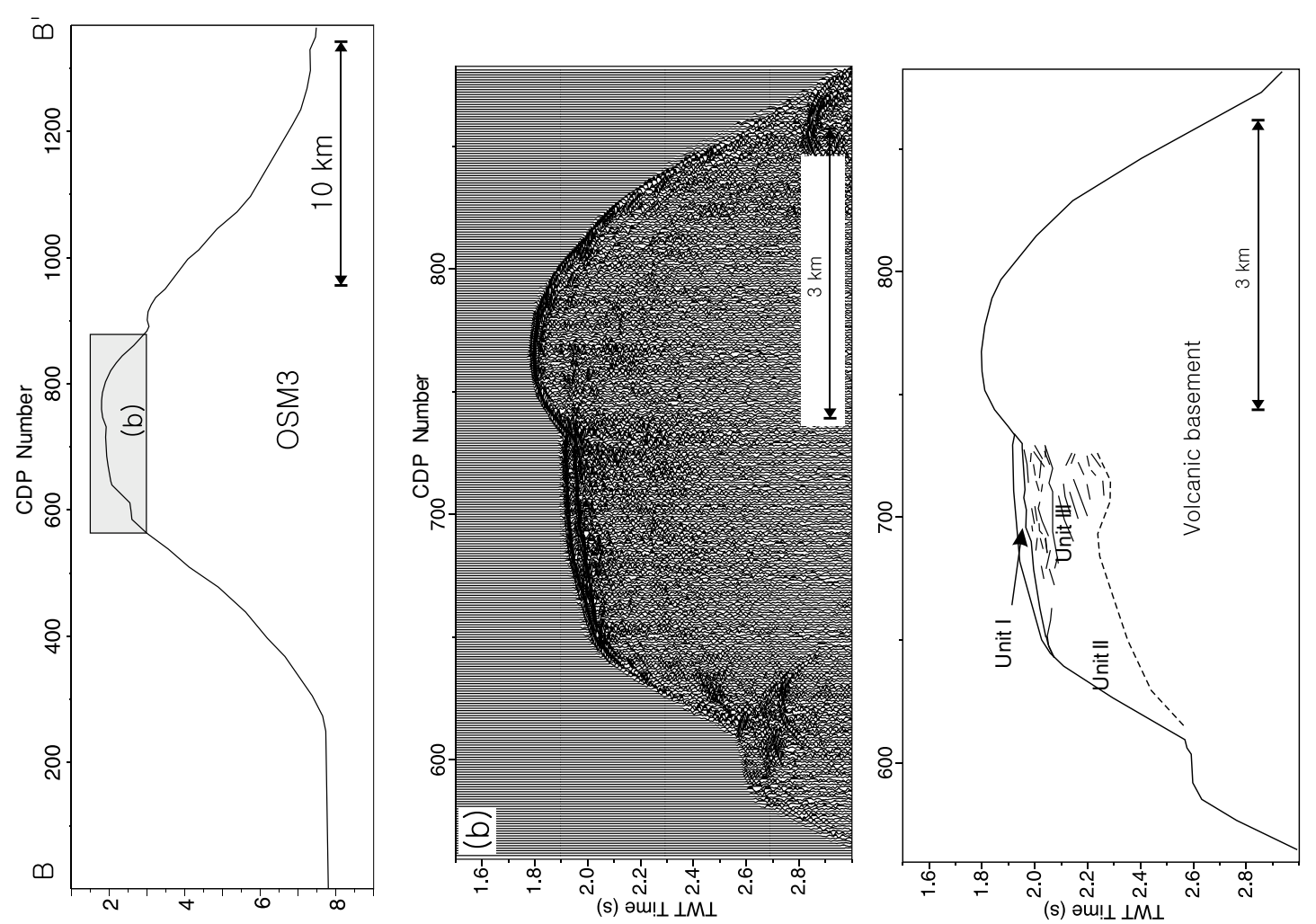

(s) əu! $\perp \perp M \perp$
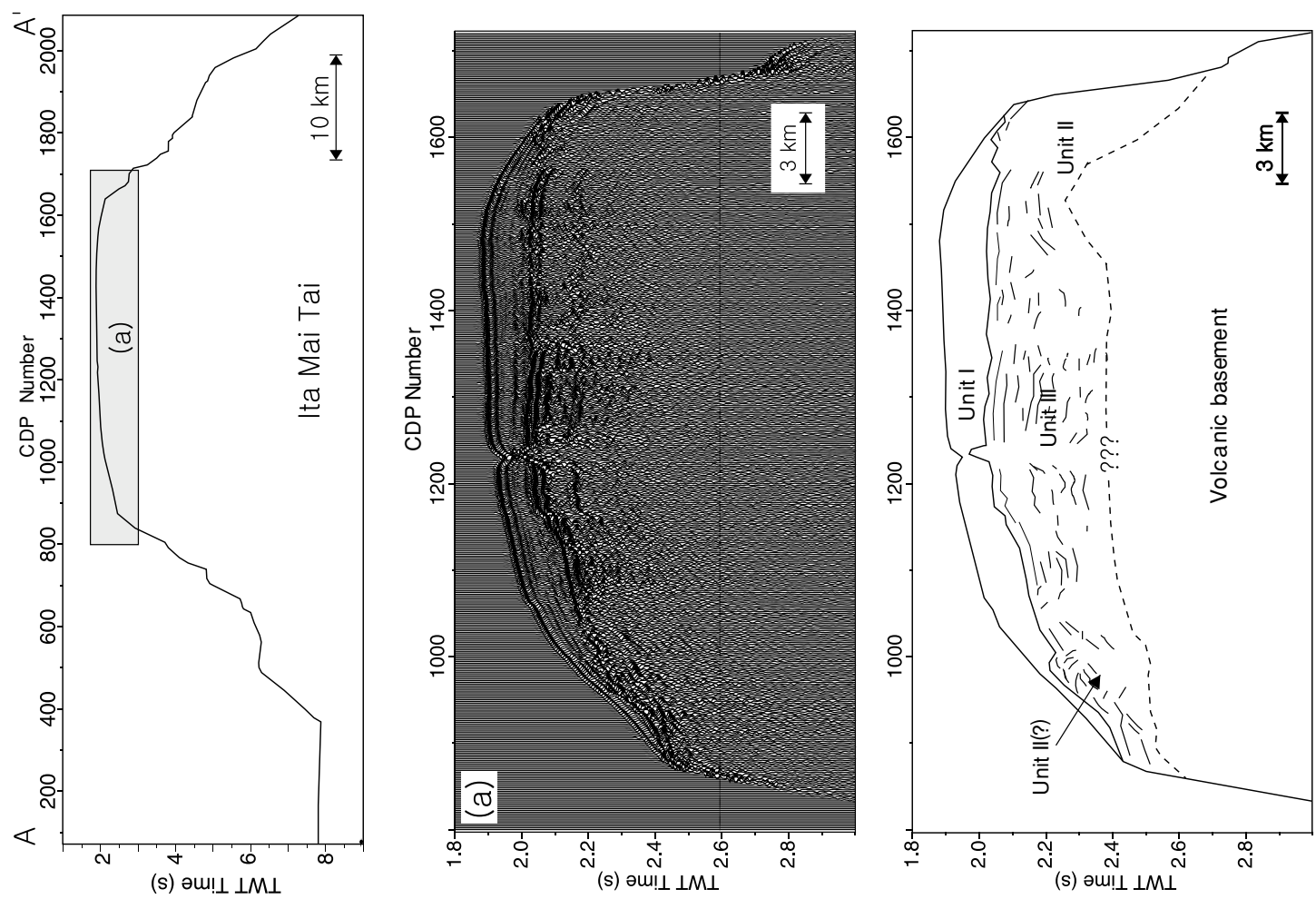

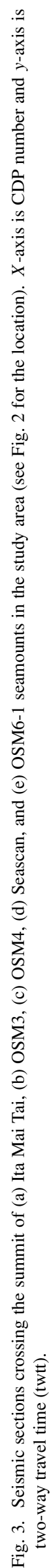



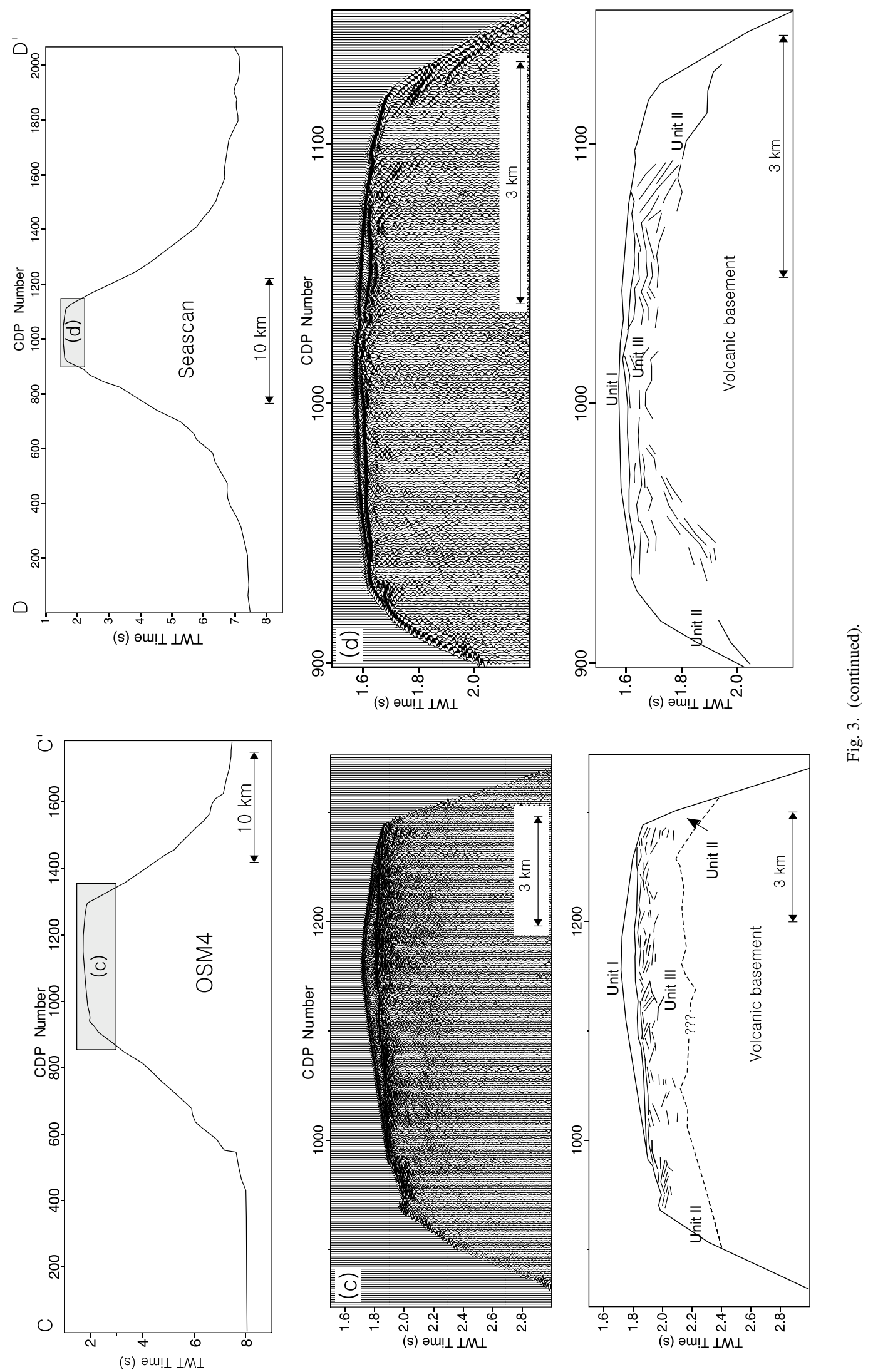

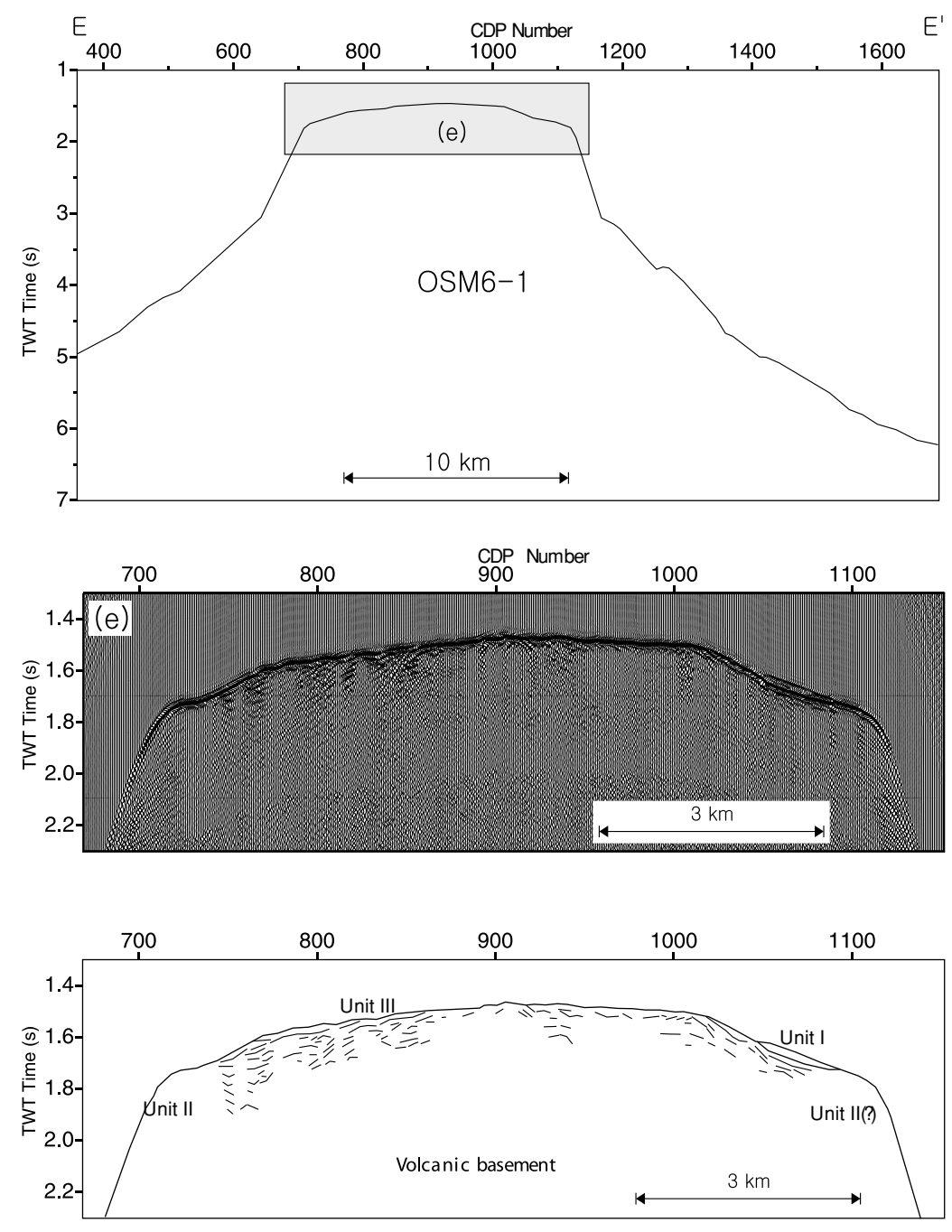

Fig. 3. (continued).

1 and OSM6-2 are less than $15 \mathrm{~m}$ (Table 1). In particular, the pelagic cap on OSM6-1 is intermittently distributed, filling lows in the irregular surface, and OSM6-2 has no pelagic cap. Unit I on OSM3 occurs only on the northwest summit, and the volcanic basement is exposed at the southeast, implying the possibility of post-shield volcanism (Fig. 3(b)). Unit II, with an internal transparency on OSM4 and Seascan, is also distinct at the summit margin, and parallel internal layers of unit III are discontinuous near unit II at the summit margin (Fig. 3(c)). The lower boundary of unit III is ambiguous on most summits of the seamounts.

We obtained dredge samples from the upper slope of the seamounts. Rock sampling at eight stations on Ita Mai Tai was attempted, but it was successful at only two stations. Shallow-water carbonates, including mudstone, were recovered on the northwest upper slope. Rock samples obtained at ten stations along the upper slope of OSM3 included shallow-water carbonates at two stations. Rock samples obtained at nine stations along the upper slope of OSM4 included shallow-water carbonates, including mollusk fragments at two stations. Dredged samples on most of the seamounts included basalt, mudstone, conglomerate, breccia, phosphorite, and tuff, in addition to shallow-water carbonates. Most seamounts in the EMB show unit II on the summit, but rock samples dredged from their slopes rarely showed rocks typical of a reef complex. Rock samples obtained from OSM5-2 and OSM6-1 consist of basalt, pelagic limestones, and conglomerate, while those from OSM6-2 also include andesite and mudstone.

\subsection{Seismic stratigraphy of the basin}

The objective of this survey was to estimate the abundance of ferromanganese crusts; therefore, the seismic survey lines were mostly confined to volcanic edifices and did not cover much of the adjacent basins. However, the small amount of seismic stratigraphy of the basins in this study is interpreted by comparison with the drill cores of DSDP site 199 in the EMB and DSDP site 585 in the OFZ (Tables 2 and 3), both of which are close to the study area (Fig. 1). The drill cores of ODP sites 800-802 also provide reference data.

4.2.1 South of the OFZ The south basin of Ita Mai Tai is about 5,860 $\mathrm{m}$ deep. Unit IV covers the uppermost part of the basin and has a thickness of about $0.14 \mathrm{~s}$ twtt (Fig. 4). Chirp subbottom profiles extending from this site reach DSDP sites 199 and 585. This unit consists of nannofossil ooze and clay and, based on drill core data, the boundary between beds is sharp (Tables 2 and 3) (Heezen et al., 1973a; Moberly et al., 1986). A piston core from 

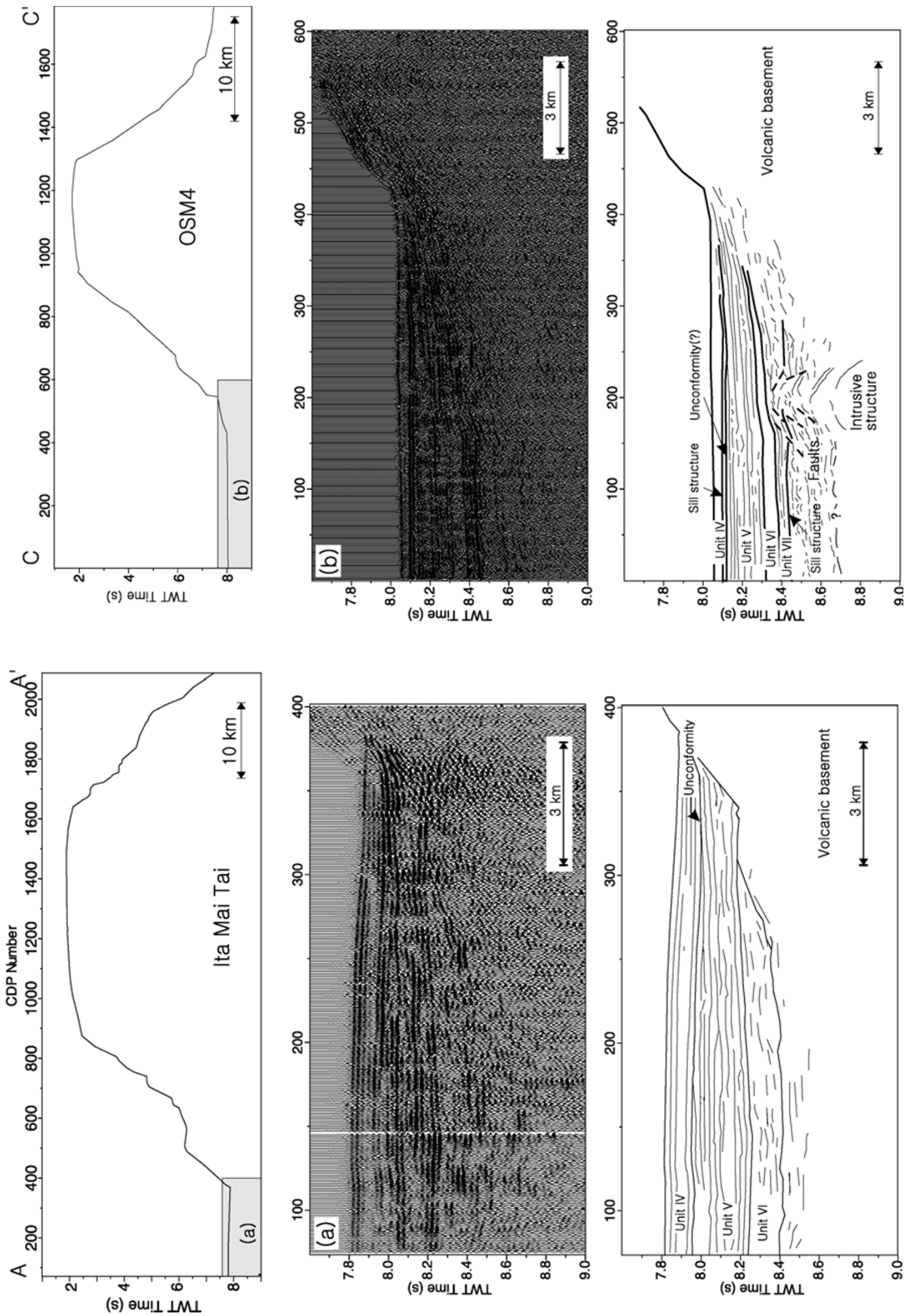

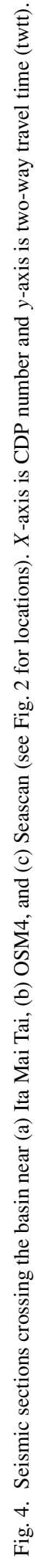



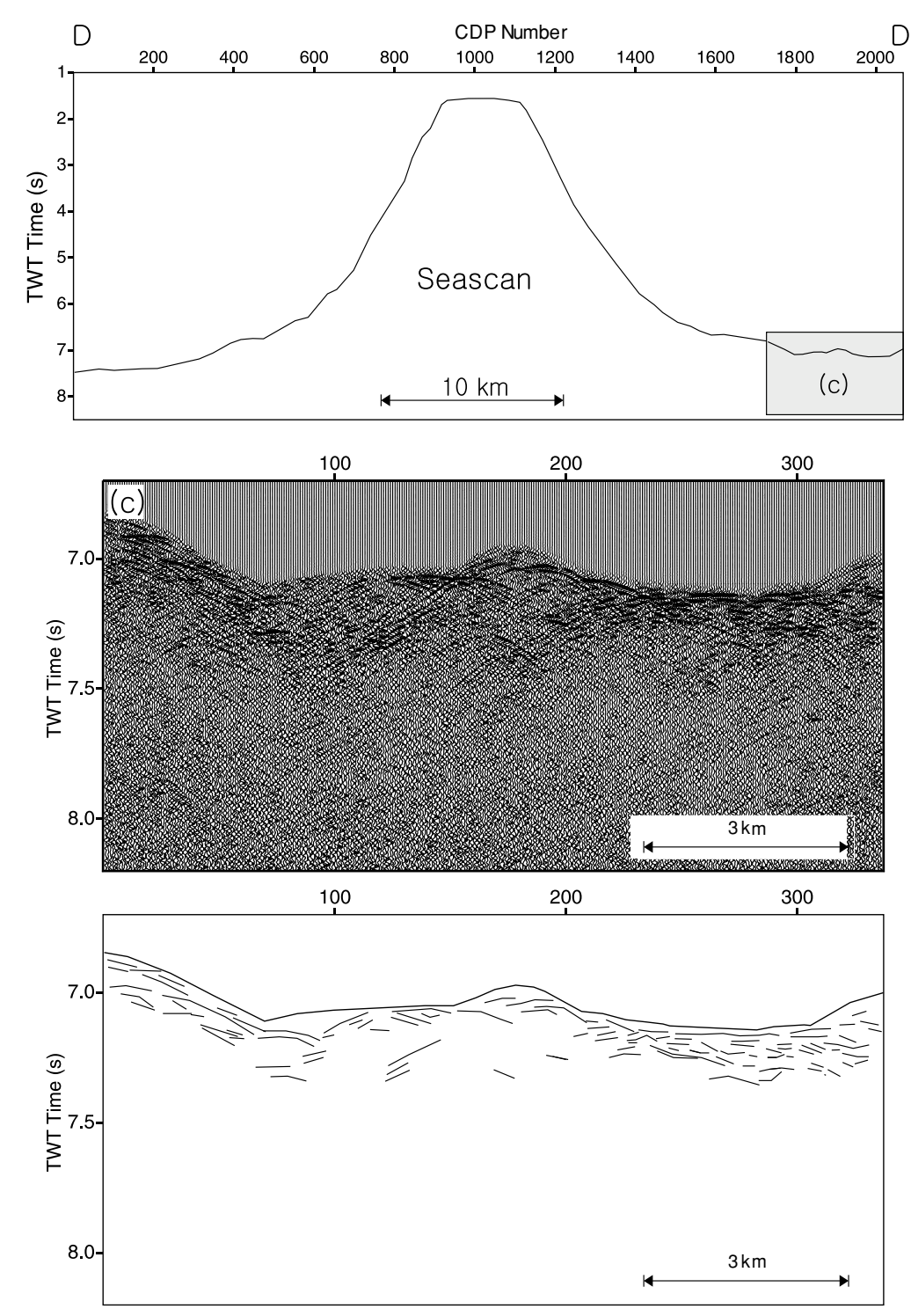

Fig. 4. (continued).

the basin floor between OSM4 and OSM5-1 indicates that unit IV is pelagic sediment. This unit may be interpreted as turbidites that grade away from the seamounts into pelagic sediments (Heezen et al., 1973a; Abrams et al., 1992). The thickness of unit $\mathrm{V}$ is constant at about $0.3 \mathrm{~s}$ twtt; based on drill cores of DSDP Site 199, this unit may be interpreted as turbidites mainly composed of nannofossil chalk, clay, and diagenetic chert partings (Heezen et al., 1973a). Unit V shows relatively strong reflectors because it may be consolidated or contain interlayered, highly reflective chert (Fig. 4). The upper part of unit $\mathrm{V}$ is truncated by unit IV, and contact between these two units appears to represent an unconformity. Unit VI with 0.17 -s twtt may be composed of redeposited claystone and radiolarian siltstone based on the drill cores of ODP site 802 (Lancelot et al., 1990) as well as volcaniclastic sediment (Heezen et al., 1973a). The layer below unit VI shows chaotic and discontinuous reflectors, and the lower boundary of unit VI seems to be concave-up. The lower layer below unit VI may be interpreted as the volcanic basement. When a seamount forms on an oceanic plate, the plate bends owing to the load and the elastic prop- erty of the plate. The flexural loading appears in the form of the moat around the seamount (Watts, 2001), which characterizes the seamounts here.

4.2.2 The OFZ The basin around OSM4 is about 6,030 $\mathrm{m}$ deep (Figs. 2 and 4(b)). Init V (0.2 s twtt) is much thicker than unit IV $(0.07 \mathrm{~s}$ twtt $)$, and, based on a comparison with drill cores of DSDP site 585, both layers are interpreted as turbidites deposited during the Eocene to Quaternary (Moberly et al., 1986; Abrams et al., 1992). Abundant and successive sills intruded along the boundary between units IV and $\mathrm{V}$, which truncated the upper part of unit $\mathrm{V}$ (Fig. 4(b)). It is probable that the sills intruded along the unconformity surface between units IV and V.

Units VI and VII near OSM4 are 0.08 and $0.06 \mathrm{~s}$ twtt, respectively (Fig. 4(b)). Abrams et al. (1992) compared seismic profiles to drill cores from DSDP site 585 with the aim of interpreting unit VI as primarily being composed of nannofossil chalk and claystone, and unit VII primarily as claystone, chert, and siltstone. Sills intruded along the lower boundary of unit VII (Fig. 4(b)). Seismic data near the boundary of the OFZ suggest that the intrusions 
Table 2. Lithology of DSDP Site 199 (Heezen et al., 1973a).

\begin{tabular}{cccc}
\hline Core & Subbottom depth $(\mathrm{m})$ & Age & Lithology \\
\hline 1 & $57.5-67.0$ & E. Pliocene & Yellowish gray Nanno-fossil ooze and brown zeolitic clay \\
2 & $67.0-76.5$ & M. Miocene & Brown, silty zeolitic clay \\
3 & $76.5-86.0$ & M. Miocene & Brown, silty zeolitic clay \\
4 & $86.0-95.5$ & E. mid Miocene & Brown, silty zeolitic clay \\
5 & $143.0-152.5$ & L. Oligocene or younger & Radiolarian ooze \\
6 & $200.0-209.5$ & M. Miocene & Gray and brown zeolitic clay, interlayered tuff \\
7 & $285.0-295.0$ & L. Paleocene & Nannofossil chalk, Limestone/chert \\
8 & $295.0-304.5$ & L. Paleocene & Nannofossil chalk, Limestone/chert \\
9 & $304.5-314.0$ & L. Paleocene & Nannofossil chalk, Limestone/chert \\
10 & $371.0-380.5$ & E. Paleocene & Limestone/chert \\
11 & $399.5-409.0$ & E. Cretaceous-E. Tertiary & Limestone/chert \\
12 & $437.5-447.0$ & L. Campanian & Chalk, brown clay, chert \\
13 & $447.0-456.5$ & - & Brown tuff \\
\hline
\end{tabular}

E, Early; M, middle; L, late.

Table 3. Lithology of DSDP Site 585 (Moberly et al., 1986).

\begin{tabular}{cccc}
\hline Core & Subbottom depth $(\mathrm{m})$ & Age & Lithology \\
\hline 1 & $0-6.8$ & Recent to E. Pleistocene & Nannofossil ooze, clay-bearing nannofossil ooze, and clay \\
2 & $256-399$ & M. Miocene to Maestrichtian & Nannofossil chalk, silicified limestone, chert, and zeolitic claystone \\
3 & $399-426$ & Maestrichtian-L. Campanian & Zeolitic claystone, nannofossil chalk and chert \\
4 & $426-485$ & Campanian & Chert and claystone \\
5 & $485-504$ & Campanian & Brown and olive black claystone \\
6 & $504-550$ & Coniacian-L. Cenomanian & Dark gray claystone \\
7 & $550-590$ & Cenomanian-M. Albian & Calcareous claystone, radiolarian claystone, and clayey limestone \\
8 & $590-893$ & M. Albian-L. Aptian & Graded sequences of volcanogenic sandstones, siltstones, and claystones \\
\hline
\end{tabular}

are common near the fracture zone (Wedgeworth and Kel$\operatorname{logg}$, 1987; Abrams et al., 1992). The acoustic layer below unit VII consists of a volcanogenic layer that originated from seamount OSM4 during its formation, based on DSDP site 585 cores and previous seismic interpretations (Moberly et al., 1986; Abrams et al., 1992).

4.2.3 North of the OFZ The basin between Seascan and OSM5-1 is about 5,330 m deep (Figs. 2 and 4(c)). It is difficult to identify the acoustic layers from the seismic survey of the basin between those two sites. From a relatively shallow depth and hummocky characteristic in the seismic profile, we infer that the seismic line does not extend into the abyssal plain, but rather is a continuation of the base of the seamount flank. The hummocky structure is interpreted as slumps originating from the seamount.

\section{Discussion}

\subsection{Seismic stratigraphy of the summit}

In this study, the contact between units I and III is sharp, and their respective acoustics are considerably different (Fig. 3). In addition, some internal reflections within unit I abut unit III at spell-out CDP (CDPs) 1140-1170 and overlap unit III at CDPs 1280-1300. Based on their study of the drill cores at DSDP site 202, Heezen et al. (1973c) stated that the top of unit III on Ita Mai Tai may be unconformable with the overlying unit I. Ooids, like those in unit III, have not been reported to occur as deep-water deposits. However, they are characteristic of shallow, calcium-carbonatesaturated waters in a coral reef environment (unit II) in which continuous, rather vigorous agitation winnows the fine sediments and constantly rotates the ooids as they grow (Heezen et al., 1973c). This implies that there were energetic currents on the summit when unit II was deposited and the seamount was near sea level. The presence of this unconformity between units I and III on Ita Mai Tai also suggests that the energetic currents existed until the seamount subsided to a considerable depth. We suggest that the seamounts of the study area experienced the same history as Ita Mai Tai, based on the consistent existence of units I, II, and III. However, the duration of strong currents on the summit of each seamount is unique and related, in part, to the subsidence rate of seamount.

There may be no statistical relationship between the elevation of the present flat-summit and either sediment thickness or stratigraphic completeness. However, Watkins et al. (1995) proposed, by comparing the pelagic cap thickness for seven guyots drilled by DSDP and ODP, that the pelagic sediment distribution of the summit in the western Pacific and their present-day latitudes are highly correlated. Thicknesses decrease to the north. A pelagic cap only exists on a few seamounts among the Japanese Seamounts, the Wake Seamounts, and the Mid-Pacific Mountains between $20^{\circ} \mathrm{N}$ and $35^{\circ} \mathrm{N}$ in the western Pacific (Van Waasbergen and Winterer, 1993). However, the Limalok $\left(5^{\circ} \mathrm{N}\right)$, Lo-En $\left(10^{\circ} \mathrm{N}\right)$, and Wodejebato $\left(12^{\circ} \mathrm{N}\right)$ seamounts in the Marshall Islands have thick pelagic caps, ranging in thickness from 50 to $150 \mathrm{~m}$ (Bogdanov et al., 1995). In the southern study area, the range of thickness of the pelagic caps is similar to that in the Marshall Islands-45-150 m. Drill cores from DSDP site 200 show that the Miocene and Pliocene were the peri- 


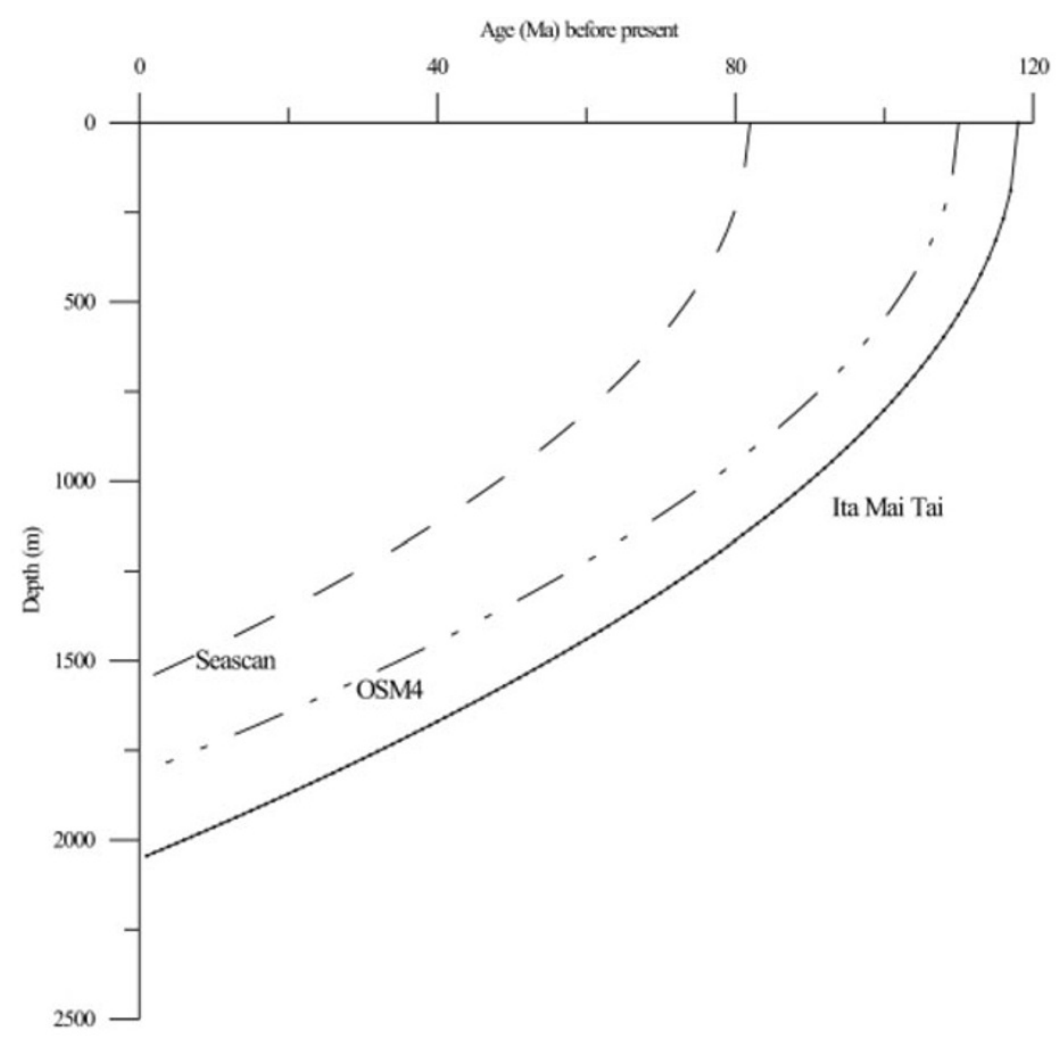

Fig. 5. Subsidence rates of Ita Mai Tai, OSM4, and Seascan. The subsided depths are inferred from seismic profiles in this study and ages estimated from paleomagnetic data by Lee et al. (2003). The seamount subsidence curves are calculated by modifying the simple cooling plate model of Parsons and Sclater (1977).

ods of high sedimentation rates for the pelagic caps (Heezen et al., 1973b). The paleolatitudes of most seamounts in the study area were between $15^{\circ} \mathrm{S}$ and $25^{\circ} \mathrm{S}$ during formation (Lee et al., 2003). The present latitudes, paleolatitudes, and the period of high sedimentation rates suggest that the seamounts of the study area have moved considerable distances since their formation and that there was high sedimentation while they were in the northern hemisphere near the equator. In contrast, the northern seamounts do not show a consistent relationship between pelagic cap thickness and their present latitude, although their latitudes are not greatly different than those of the southern seamounts. The northern seamounts in the study area may have been affected by local currents that eroded the caps or prevented them from accumulating. In addition, the thickness of the pelagic cap may have been affected by the flatness of the summit, the area of the flat summit, and the development of a reef complex at the summit margin.

In general, while the volcanic islands subsided after formation, the reefs on the summit continued to grow up to sea level, eventually burying the volcanic basement. These reefs formed a carbonate platform, most often in the form of an atoll, before the subsidence that produced the guyots. Therefore, if the lower limit of the reef complex were to be identified, then the subsidence depth of the seamount could be inferred. Wedgeworth and Kellogg (1987) proposed that Ita Mai Tai subsided over 2,090 m, which is comparable to the subsidence determined for other seamounts in the area, such as Kwajalein (2,000 m) and Enewetak (1,900 m) (Jones, 1973). In our study, the subsidence depth of Ita Mai
Tai is about 2,040 $\mathrm{m}$ and those of OSM4 and Seascan are 1,800 and 1,550 $\mathrm{m}$, respectively. Based on seamount paleomagnetic data, Seascan is younger than Ita Mai Tai and OSM4 (Lee et al., 2003), which is consistent with the subsidence depth as well as the depths of the summit and base. However, this method must be used with caution because the depth can be affected by rejuvenation of the lithosphere, the thermal stress near the fracture zone, post-shield volcanism, among others.

From the subsidence depths and estimated ages (Fig. 5) (Koppers et al., 1998; Lee et al., 2003), Seascan seems to have had a higher subsidence rate than Ita Mai Tai and OSM4, although Ita Mai Tai, with a large volume and older age, likely also had a high subsidence rate. Menard (1984) suggested the 'Darwin rise' hypothesis from the shallower depth anomaly of the central and western Pacific. Many researchers have proposed that the central and western Pacific basin was the site of widespread intraplate volcanism during one or two intervals in the Cretaceous (e.g., Matthews et al., 1974; Winterer, 1976a, b; Rea and Vallier, 1983). The estimated age of Seascan is consistent with the last pulse of widespread volcanic activity (Schlanger and Premoli-Silva, 1981; Schlanger et al., 1981; Lee et al., 2003), and the lithosphere was rejuvenated by the widespread volcanism. Lee et al. (2009) also proposed the possibility of rejuvenation, based on the result that the lithosphere beneath the study area has an anomalously thin elastic thickness. Ita Mai Tai and OSM4 have been uplifted twice or more by volcanism and rejuvenation of the lithosphere, but the amount of the uplift is not known. Therefore the subsidence rates of Ita 
Mai Tai and OSM4 appear to be lower than that of Seascan. 5.2 Seismic stratigraphy of the basin

Unit IV in the basin near Ita Mai Tai and OSM4 is exceptional in that it overlays unit V (Fig. 4(a) and (b)). The internal layers in unit $\mathrm{V}$ are truncated by unit IV. Based on cores from DSDP site 199, Heezen et al. (1973a) proposed that there were bottom currents during the Middle Miocene, as indicated by primary sedimentary structures that possess sharp boundaries, are parallel-laminated at the bottom, and then gradually become coarser upward with shale chips. Abrams et al. (1992) proposed that the drill cores from ODP site 800 to the northwest of the study area show a hiatus between the Miocene and underlying Late Cretaceous sediments. These results suggest that the unconformity in the basin may be widespread and extend from the PB to EMB, but that the unconformity on the summit of seamounts is not widespread because of local currents and subsidence rates.

Wedgeworth and Kellogg (1987) found that predominantly clay and nannofossil ooze characterize the 0 - and 256-mbsf interval at DSDP site 585 and that its maximum age is Pleistocene (Table 3 ). The cores seem not to include the interlayered tuff that has been found in Miocene cores from DSDP site 199, despite the fact that the two sites are close, $60-70 \mathrm{~km}$. The sediment between 6.8 and $256 \mathrm{mbsf}$ at DSDP site 585 was not recovered. Therefore, it is possible that the layer between 0 and $256 \mathrm{mbsf}$ at DSDP site 585 deposited during the Cenozoic includes volcanogenic sediment of the Miocene age. Abrams et al. (1992) proposed, based on their interpretation of seismic profiles near our study area, that tuff sediment of Miocene age originated from volcanism at the Caroline hotspot located to the southeast of the study area and that it was distributed widely throughout the EMB and OFZ.

The study area belongs to the Jurassic Quiet Zone (JQZ), which is the oldest part of the Pacific. The basin near the northern study area is much shallower than that near the southern area. The northern basin is shallower than the depth calculated from the cooling plate model (Parsons and Sclater, 1977). The depth difference can be explained by either rejuvenation or a volcanic swell, such as the Hawaiian ridge. The seismic profile of the basin near Seascan shows that the acoustic layers are not as well developed as at Ita Mai Tai and OSM4 (Fig. 4), and that the layer with hummocky characteristics was deposited by slumping. This indicates that the seismic survey line near Seascan does not image the basin, but that it is part of the Seascan volcanic edifice or, alternatively, a volcanic swell.

\section{Conclusions}

We reached the following conclusions based on our interpretations of the seismic and bathymetric records.

1) Three acoustic units are identified on the seismic reflection profiles taken over the summit of seamounts: an uppermost transparent layer (unit I); a chaotic or transparent layer with an irregular surface (unit II); a lower layered unit (unit III). We also identified four units in the seismic profiles taken in basins: an uppermost transparent layer with weak internal reflectors (unit IV); an upper well-layered unit with a high am- plitude (unit V); a lower transparent layer (unit VI); a lower well-layered and thin unit with a high amplitude (unit VII).

2) Unit I (pelagic cap) is exceptional in that it overlays unit III (shallow carbonate deposit), indicating that energetic currents existed until the seamounts subsided to considerable depths. The period of strong currents on the summit of seamounts is unique to each seamount.

3) We infer that seamounts subsided between $1,550 \mathrm{~m}$ (Seascan) and 2,040 $\mathrm{m}$ (Ita Mai Tai) after their formation based on interpretations of the origins of the seismic units on the summits of the seamounts. The southern seamounts subsided more than northern ones.

4) Seismic stratigraphy at the base of Ita Mai Tai and OSM4 shows an unconformity between units VI and $\mathrm{V}$. Based on seismic profiles and drill cores, the unconformity in the basins may be widespread and extend through the PB to EMB.

5) The basin near the northern boundary of the study area is much shallower than that near the southern boundary, and it is shallower than the depth calculated from the cooling plate model. The difference in depth may have been caused by the uplift of the lithosphere rejuvenated by the younger volcanism of the northern seamounts, which is consistent with widespread volcanism.

Acknowledgments. We would like to thank the crew of the R/V Onnuri and on-board researchers for their assistance during the cruises. We also thank two reviewers for their constructive and helpful comments which helped improve the paper. This work was supported by a R\&D Project (PM138-01) of the Korean Ministry of Maritime Affairs and Fisheries.

\section{References}

Abrams, L. J., R. L. Larson, T. H. Shiply, and Y. Lancelot, The seismic stratigraphy and sedimentary history of the East Mariana and Pigafetta basins of the western Pacific, in Pro. ODP Sci. Results, edited by R. L. Larson, Y. Lancelot, A. Fisher, and E. L. Winterer, 551-569, College Station, Washington D.C., 1992.

Bogdanov, Y. A., O. Y. Bogdanova et al., Composition of ferromanganese crusts and nodules at northwestern Pacific guyots and geologic and paleoceanographic considerations, in Proc. ODP, Sci. Results, edited by J. A. Haggerty, I. Premoli Silva, F. R. Rack, and M. K. McNutt, 745768, College Station, Washington D.C., 1995.

Heezen, B. C., I. D. MacGregor et al., Mesozoic chalks beneath the Caroline abyssal plain: DSDP Site 199, in Init. Repts. DSDP, edited by B. C. Heezen and I. D. MacGregor, 65-85, U.S. Government Printing Office, Washington D.C., 1973a.

Heezen, B. C., I. D. MacGregor et al., Tertiary pelagic ooze on Ita MaiTai guyot, equatorial Pacific: DSDP Sites 200 and 201, in Init. Repts. DSDP, edited by B. C. Heezen and I. D. MacGregor, 87-96, U.S. Government Printing Office, Washington D.C., 1973b.

Heezen, B. C., I. D. MacGregor et al., Oolitic limestone on the Ita MaiTai guyot, Equatorial Pacific: DSDP Site 202, in Init. Repts. DSDP, edited by B. C. Heezen and I. D. MacGregor, 97-102, U.S. Government Printing Office, Washington D.C., 1973c.

Jones, E. J. W., Determination of sedimentary velocities using expendable sonobuoys at DSDP Leg 20 drilling sites, northwest Pacific, in Init. Repts. DSDP, edited by B. C. Heezen and I. D. MacGregor, 625-642, U.S. Government Printing Office, Washington D.C., 1973.

Koppers, A. A. P., H. Staudigel, J. R. Wijbrans, and M. S. Pringle, The Magellan seamount trail: implications for Cretaceous hotspot volcanism and absolute Pacific plate motion, Earth Planet. Sci. Lett., 163, 53-68, 1998.

Lancelot, Y., R. L. Larson et al., Proc. ODP, Init. Repts., 129, College Station, Washington D.C., 1990. 
Lee, T. G., S. M. Lee, J. W. Moon, and K. Lee, Paleomagnetic investigation of seamounts in the vicinity of Ogasawara Fracture Zone northwest of the Marshall Islands, western Pacific, Earth Planets Space, 55, 355$360,2003$.

Lee, T. G., J. R. Hein, K. Lee, J. W. Moon, and Y. T. Ko, Sub-seafloor acoustic characterization of seamounts near the Ogasawara Fracture Zone in the western Pacific using chirp $(3-7 \mathrm{kHz})$ subbottom profiles, Deep-Sea Research Part I, 52, 1932-1956, 2005.

Lee, T. G., J. W. Moon, and M. S. Jung, Three-dimensional flexure modelling of seamounts near the Ogasawara Fracture Zone in the western Pacific, Geophys. J. Int., doi:10.1111/j.1365-246X.2008.04054.x, 2009.

Lincoln, J. M., M. S. Pringle, and I. P. Silva, Early and Late Cretaceous Volcanism and Reef-Building in the Marshall Islands, in The Mesozoic Pacific: Geology, Tectonics, and Volcanism, edited by M. S. Pringle, W. W. Sager, W. V. Sliter, and S. Stein, 279-305, AGU, Washington D.C., 1993.

Matthews, J. L., B. C. Heezen, R. Catalano, A. Coogan, M. Tharp, J. Natland, and M. Rawson, Cretaceous drowning of reefs on mid-Pacific and Japanese Guyots, Science, 184, 462-464, 1974.

Menard, H. W., Darwin reprise, J. Geophys. Res., 89, 9960-9968, 1984.

Moberly, R., S. O. Schlanger et al., Init. Repts. DSDP, 89, U.S. Government Printing Office, Washington D.C., 1986.

Nakanishi, M., K. Tamaki, and K. Kobayashi, Mesozoic magnetic anomaly lineations and seafloor spreading history of the northwestern Pacific, $J$. Geophys. Res., 94, 15437-15462, 1989.

Nakanishi, M., K. Tamaki, and K. Kobayashi, Magnetic anomaly lineations from Late Jurassic to Early Cretaceous in the west-central Pacific Ocean, Geophys. J. Int., 109, 701-719, 1992.

Parsons, B. and J. G. Sclater, An analysis of the variation of ocean floor bathymetry and heat flow with age, J. Geophys. Res., 82, 803-827, 1977.

Pringle, M. S., Radiometric ages of basaltic basement recovered at Sites 800, 801, and 802, Leg 129, western Pacific Ocean, in Proc. ODO Sci. Res., edited by R. L. Larson, Y. Lancelot et al., 389-404, College Station, Washington D.C., 1992.

Rea, D. K. and T. L. Vallier, Two Cretaceous volcanic episodes in the western Pacific Ocean, Geol. Soc. Am. Bull., 94, 1430-1437, 1983.

Sager, W. W., Seamount Paleomagnetism and Pacific Plate Tectonics, PhD thesis, University of Hawaii, 1983.

Sager, W. W., Seamount age estimates from Paleomagnetism and their implications for the history of volcanism on the Pacific plate, in Geology and offshore mineral resources of the Central Pacific basin, CircumPacific Council for Energy and Mineral Resources Earth Science Series, edited by B. H. Keating and B. R. Bolton, 21-37, Springer-Verlag, N.Y., 1992.

Schlanger, S. O. and I. Premoli-Silva, Tectonic, volcanic, and paleogeographic implications of redeposited reef faunas of Late Cretaceous and Tertiary age from the Nauru Basin and Line Islands, in Init. Repts.
DSDP, edited by R. L. Larson and S. O. Schlanger, 61, 817-827, U.S. Government Printing Office, Washington D.C., 1981.

Schlanger, S. O., H. C. Jenkyns, and I. Premoli-Silva, Volcanism and vertical tectonics in the Pacific basin related to global Cretaceous transgressions, Earth Planet. Sci. Lett., 52, 435-449, 1981.

Schlanger, S. O., J. F. Campbell, and M. W. Jackwon, Post-Eocene subsidence of the Marshall Islands recorded by drowned atolls on Harrie and Sylvania Guyots, in Seamounts, Islands, and Atolls, edited by B. H. Keating, P. Freyer, R. Batiza, and G. W. Boehlert, 165-174, American Geophysical Union, Washington D.C., 1987.

Van Waasbergen, R. J. and E. L. Winterer, Summit geomorphology of western Pacific guyots, in The mesozoic Pacific: Geology, Tectonics, and Volcanism, edited by M. S. Pringle, W. W. Sager, W. V. Sliter, and S. Stein, 335-366, AGU, Washington D.C., 1993.

Watkins, D. K., P. N. Pearson, E. Erba, F. Rack, I. Premoli Silva, H. W. Bohrmann, J. Fenner, and P. R. N. Hobbs, Stratigraphy and sediment accumulation patterns of the Upper Cenozoic pelagic carbonate caps of guyots in the northwestern Pacific ocean, in Proc. ODP, Sci. Results, edited by J. A. Haggerty, I. Premoli Silva, F. Rack, and M. K. McNutt, 675-689, College Station, 1995.

Watts, A. B., Isostasy and Flexure of the Lithosphere, Cambridge University Press, Cambridge, 2001.

Wedgeworth, B. and J. Kellogg, A 3-D gravity-tectonic study of Ita Mai Tai guyot: An uncompensated seamount in the East Mariana Basin, in Seamounts, Islands, and Atolls, edited by B. H. Keating, P. Freyer, R. Batiza, and G. W. Boehlert, 73-84, AGU, Washington D.C., 1987.

Wessel, P. and L. W. Kroenke, A geometric technique for relocating hotspots and refining absolute plate motions, Nature, 387, 365-369, 1997.

Winterer, E. L., Bathymetry and regional tectonic setting of the Line Islands Chain, in Init. Repts. DSDP, edited by S. O. Schlanger and E. D. Jackson, 33, 731-748, U.S. Government Printing Office, Washington D.C., 1976a.

Winterer, E. L., Anomalies in the tectonic evolution of the Pacific, in The geophysics of the Pacific Ocean Basin and its Margins, edited by G. H. Sutton, M. H. Manhnani, and R. Moberly, 731-748, AGU, Washington D.C., $1976 b$.

Winterer, E. L., R. A. Duncan, M. K. McNutt, J. H. Natland, I. Premoli Silva, W. W. Sager, W. V. Sliter, R. van Waasbergen, and C. J. Wolfe, Cretaceous guyots in the northwest Pacific: An overview of their geology and geophysics, in The mesozoic Pacific: Geology, Tectonics, and Volcanism, edited by M. S. Pringle, W. W. Sager, W. V. Sliter, and S. Stein, 307-334, AGU, Washington D.C., 1993. Moon

T.-G. Lee (e-mail: tglee@knoc.co.kr), K. Lee, J. R. Hein, and J.-W. 